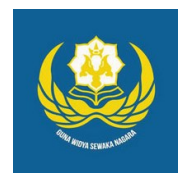

Jurnal Analogi Hukum

Journal Homepage: https://ejournal.warmadewa.ac.id/index.php/analogihukum

\title{
Pemberian Ganti Rugi Terhadap Pengadaan Tanah Oleh Pemerintah Untuk Kepentingan Umum
}

\author{
Luh Nyoman Diah Sri Prabandari*, I Wayan Arthanaya dan Luh Putu Suryani \\ Universitas Warmadewa, Denpasar-Bali, Indonesia \\ *diahsriprabandari@gmail.com

\begin{abstract}
How To Cite:
Prabandari, L, N, D, S., Arthanaya, I, W., Suryani, L, P. (2021). Pemberian Ganti Rugi Terhadap Pengadaan Tanah Oleh Pemerintah Untuk Kepentingan Umum. Jurnal Analogi Hukum. 3 (1). 1-5. Doi: https://doi.org/10.22225/ah.3.1.2920.1-5
\end{abstract}

\begin{abstract}
Land purchasing is an activity taken by government in order to build public fasilities, purchasing also done by giving some compesation to society that affected. During purchasing activity never runs smooth, where mostly some people who gets land purchase is not santisfied with the amount of compensation that given by government. Regarding those matters, we may conclude there are 2 problems those are : 1 . What Is the juridical basis for land acquistion in the public interest?, 2. How is the mechanism of compesation in land purchasing for public that held by goverment?. Research that an be used to solve the problem is normatif research method by studying the valid rules. Juridis platform land purchasing is President policy no 71 year 2012 about land enforcement to public needs, the regulation no 2 year 2012 about land purchasing for public developing. Compensation mechanism on land purchasing must be based on the forum between committee and the right holder of the land or plants that's exist on it, that during the interpretation or the quotation the amount of compensation should be agreed and must be based on the local public price.
\end{abstract}

Keywords: compensation; land acquisition; public interest

\begin{abstract}
Abstrak-Pengadaan tanah merupakan kegiatan pengambilan tanah oleh pemerintah dalam rangka menyelenggarakan pembangunan untuk kepentingan umum pengadaan tanah disertai dengan pemberian ganti rugi terhadap masyarakat yang terkena pengadaan tanah. Dalam pelaksanaanya pengadaan tanah tidak selalu berjalan mulus dimana seringkali terdapat warga masyarakat yang terkena pengadaan tidak puas dengan besarnya nilai gantirugi yang diberikan pemerintah. Sehubungan dengan hal tersebut maka dapat dirumuskan dua permasalahan yaitu: 1. Apakah yang menjadi landasan yuridis dalam pengadaan tanah untuk kepentingan umum yang dilaksanakan oleh pemerintah?, 2. Bagaimana mekanisme pemberian ganti rugi dalam pengadaan tanah untuk kepentingan umum yang dilaksanakan oleh pemerintah?. Metode penelitian yang digunakan dalam memecahkan permasalahan tersebut adalah metod penelitian normatif dengan dengan mengkaji peraturan perundang-undangan yang berlaku. Yang menjadi landasan yuridis pengadaan tanah adalah perpres nomor 71 tahun 2012 tentang penyelenggaraan tanah untuk kepentingan umum, Undang-Undang nomor 2 Tahun 2012 Tentang Pengadaan Tanah bagi pembangunan untuk kepentingan umum. Mekanisme ganti rugi dalam pengadaan tanah haruslah berdasarkan musyawarah antara panitia dan pemegang hak atas tanah atau tanaman yang berada diatasnya ini berarti bahwa didalam mengadakan penafsiran atau penetapan besarnya ganti rugi haruslah tercapainya kata sepakat dan haruslah berdasarkan harga umum setempat .
\end{abstract}

Kata kunci: Ganti Rugi; Pengadaan Tanah; Kepentingan Umum.

\section{Pendahuluan}

Tanah merupakan kebutuhan pokok yang sangat dibutuhkan bagi kehidupan seluruh manusia, karena tanah merupakan salah satu unsur utama bagi kelangsungan hidup dan kehidupan manusia sepanjang masa, dengan tujuannya adalah dipergunakan untuk tercapainya kemakmuran bagi seluruh rakyat yang terbagi secara merata baik secara materil maupun spritual (Novita, 2014). Tanah di Indonesia pada dasarnya sudah ada yang memiliki atau sudah menempati. Pentingnya tanah bagi kehidupan manusia, sehingga tidak heran dan tidak jarang jika setiap manusia ingin memilikinya, yang bisanya menimbulkan akibat hukum atau perbedaan pendapat atau perselisihan atau bahkan pertentangan di kalangan keluarga terhadap penguasaan/ pemilikan mengenai tanah, bahkan banyaknya 
kasus sengketa batas tanah dengan hak milik, di dalam masyarakat (baik karena tidak jelasnya batas Sebelah Barat; Sebelah Timur; maupun batas Sebelah Selatan dan Sebelah Utara) (Syahri, 2014). Mengakibatkan ialah dalam pembangunan yang membutuhkan tanah maka ditempuh dengan cara mengambil tanah hak , pengambilan tanah yang dilakukan oleh pemerintah yang dipergunakan untuk pembangunan demi kepentigan umum yaitu disebut pengadaan tanah yang diwajibkan adanya ganti kerugian (Syah, 2010). Kebutuhan pembangunan di Indonesia banyak sekali memerupakan tanah dimana dalam hal ini terjadi suatu perbuatan hukum pemindahan hakhak atas tanah, tanah ini sengaja beralih terhadap pihak lain. Hak atas tanah ini dapat dipindahkan dengan cara jual beli dan tukar menukar kebijakan

Pada kenyataannya dalam praktiknya pengadaan tanah bagi pembangunan untuk kepentingan umum terkadang sering timbul permasalahan antara pemerintah dengan masyarakat terutama dalam hal ganti kerugian dalam pengdaan tanah. Pelaksanaan pengadaaan tanah tersebut dilakukan degan memperhatikan kegunaan tanah pada kehidupan manusia dan prinsip pada hak-hak yang sah atas tanah. Mengenai prosedur pengadaan tanah pada prinsipnya sangatlah baik namun prinsip dari kebudayaan masyarakatlah yang dimana masyarakat memiliki anggapan bahwa hak atas tanah adalah hak yang mutlak yang konsekuensinya masyarakat beranggapan bahwa masyarakatlah yang akan menentukan besarnya ganti rugi untuk mengubah pandangan masyarakat ini pemerintah perlu mencari persamaan pandangan antara pemerintah dengan masyarakat. Selama tidak adanya persamaan pandangan antara pemerintah dengan masyarakat maka permasalahan akan selalu timbul yang dimana masyarakat tidak tidak puas dengan berapa besar ganti rugi yang diberikan oleh pemerintah.

Pihak masyarakat selalu menginginkan harga ganti rugi yang sangat tinggi bahkan melebihi harga setempat, dan ada juga masyarakat yang menginginkan besarnya harga gani rugi didasarkan dengan harga sekian tahun kedepan. Pemeritah dalam menentukan besarnya ganti kerugian berpedoman pada Nilai Jual Objek Pajak (NJOP) yang besarannya ditentukan oleh kantor Pajak Bumi Dan Bangunan (PBB) berdasarkan realitas, harga pasaran di masyarakat lebih tinggi dari NJOP.

Dari latar belakang tersebut diatas maka dapat dirumuskan dua permasalahan yaitu, Apakah yang menjadi landasan yuridis dalam pengadaan tanah untuk kepentingan umum oleh pemerintah dan bagaimana mekanisme pemberian ganti rugi dalam pengadaan tanah untuk kepentingan umum yang dilaksanakan oleh pemerintah.

Penelitian ini bertujuan untuk mengkaji landasan yuridis dalam pengadaan tanah untuk kepentingan umum yang dilakukan oleh pemerintah, dan bertujuan mengkaji serta merumuskan suatu mekanisme pengadaan tanah yang lebih menjamin hak-hak warga masyarakat yang terkena pengadaan atas ganti rugi yang layak.

Dalam memecahkan permasalahan yang terjadi maka metode yang digunakan adalah metode penelitin dengan tipe penelitian Normatif yang mempelajari peraturan perundang-undangan dan buku-buku yang terkait dengan permasalahan ini, bersumber dari data primer yaitu bersumber dari bahan-bahan hukum yang berkaitan dengan permasalahan tersebut berupa peraturan perundang-undangan dan sumber data sekunder yaitu bahan- bahan hukum yang diperoleh dari pengkajian kepustakaan.

Teknik pengumpulan data yang digunakan adalah studi kepustakaan atau sudi dokumen dimana teknik ini mempelajari dan mencatat membaca doktrin-doktrin catatan literature, dan setelah data terkumpul pengolahan data dilakukan dengan cara mensistematiskan terhadap bahan-bahan hukum tertulis.

\section{Hasil dan Pembahasan}

\section{Landasan Yuridis dalam Pengadaan Tanah oleh Pemerintah Untuk Kepentungan Umum}

Pengadaan tanah merupakan kegiatan pelepasan hak atas tanah yang dimana bertujuan untuk kepentingan umum dan disertai dengan ganti kerugian. Yang dimaksud dengan kepentingan umum adalah keperluan untuk orangbanyak atau kebutuhan orangbanyak atas dasat kepentingan orang banyak dan tujuan sosial yang luas. (Salindeho, 2008)

Asas-asas dalam pengadaan tanah di tentukan dalam pasal 2 Undang-Undang Nomor 2 Tahun 2012 Tentang Pengadaan Tanah bagi pembangunan untuk Kepentingan umum:

\section{Kemanusiaan}

Pengadaan tanah wajib memberikan perlindungan serta penghormatan terhadap hak asasi manusia harkat serta mrtabat yang dimiliki setiap warga negara 
Keadilan

Memberikan jaminan penggatian yang layak terhadap pihak yang berhak agar mendapatkan kehidupan yang layak

\section{Kemanfaatan}

Pengadaan tanah dapat memberi mamfaat bagi masyarakat Bangsa dan Negara.

\section{Kepastian}

Mendapatkan kepastian hukum bagi masyarakat yang terkena pengadaan tanah

\section{Keterbukaan}

Keterbukaan disini dimaksud adaya akses untuk mendapatkan informasi tentang penyelenggaraan pengadaan tanah

\section{Kesepakatan}

Kesepakatan yang dimaksud adalah dalam proses pengadaan tanah harus terjadi kesepakatan antara masyarakat dengan pemerintah dengan jalan musyawarah

\section{Keikut sertaan}

Keikut sertaan masyarakat dalam pengadaan tanah mulai dari perencaaan pengadaan tanah .

Sebelumnya pengadaan tanah diseut dengan pembebasan tanah yang dimana diatur dalam Permengadri Nomor 15 tahun 1975 tentang ketentuan-ketentuan tata cara pengadaan tanah kemudian seiring berjalannya waktu untuk meminimalisir permasalahan yang terjadi maka pembebasan tanah diganti dengan pengadaan tanah yang dimana diatur dalam Perpres Nomor 71 tahun 2012 Tentang penyelenggaraan tanah bagi pembangunan untuk kepentingan umum perubahan pertama perpres Nomor 40 tahun 2014 dan perubahan kedua perpres Nomor 99 tahun 2014 tentang penyelenggaraan pengadaan tanah untuk pembangunan bagi kepentingan umum serta Undang-Undang Nomor 2 Tahun 2012 Tentang pengadaan tanah bagi kepentingan umum serta Undang-Undang Nomor 5 Tahun 1960 tentang dasar Pokok-pokok Agraria. (Parangi, 2008)

Dimana prosedur dalam pengadaan tanah dalam pembangunan untuk kepentingan umum :

\section{Perencanaan pengadaan tanah}

Dalam perencanaan pengadaan tanah untuk kepentingan umum didasarkan atas tata ruang wilayah. Perencanaan pengadaan tanah dibentuk dalam suatu dokumen yang memuat tentang

Maksud serta tujuan pembangunan

Kesesuaian antara tataruang dan rencana pembangunan

Lokasi tanah

Luas tanah

Gambar situasi tanah tanah

Tenggang waktu pelaksanaan pengadaan

Tenggang waktu pembangunan pengadaan tanah

Perkiraan nilai tanah

Rencana pembangunan.

Persiapan pengadaan tanah

Diamana pemrintah dengan intansi pengadaan tanah melakukan pemberitahuan rencana pembangunan, pendataan awal lokasi rencana pembangunan konsultasi publik rencana pembangunan.

\section{Pelaksanaan Pengadaan Tanah}

Berdasarkan penetapan hasil lokasi instansi yang bersangkutan mengajukan pelaksanaan tanah kepada badan pertanahan. Dalam pelaksanaan pengadaan tanah meliputi:

Penilaian ganti rugi

Musyawarah penetapan ganti rugi

Pemeberian ganti rugi

Pelepasan tanah Instansi.

Penyerahan hasil pengadaan tanah

Badan pertanahan menyerahkan hasil kepada instansi yang memerlukan tanah padasaat sudah:

Pemberian ganti kerugian kepada pihak yang berhak dalam pengadaan tanah atau kepada masyarakat yang terkena pengadaan tanah,

Atau setelah pemberian ganti rugi yang dititipkan di pengadilan Negeri, Mahkamah agung

Setelah semua proses tersebut selesai maka instansi yang memerlukan tanah tersebut dapat melaksanakan pembangunan .

Mekanisme Pemberian Ganti Rugi dalam 


\section{Pengadaan Tanah oleh Pemerintah untuk Kepentingan Umum}

Pengadaan tanah di Indonesia seringkali diwarnai dengan konfik dimana masyarakat tidak puas dengan besarnya ganti kerugian dalam pengadaan tanah. Pada hakekatnya ganti rugi sangatlah melekat pada pengadaan tanah dimana hal ini ditentukan dalam pasal 1 ayat 2 Undang-Undang Nomor 2 Tahun 2012 Tentang Pengadaan Tanah Bagi pembangunan Untuk Kepentingan Umum.

Pelaksnaan pengadaan tanah dilakukan oleh pelaksana pengadaan tanah yang berdasarkan jasa dan penilaian publik hal ini ditentukan dalam pasal 67 Perpres Nomor 71 tahun 2012 tentang penyelenggaraan pengadaan tanah bagi pembangunan untuk kepentingan umum.

Di prosedur pelaksanaan pengadaan taah yang dimana diatur dalam Undang- Undang Nomor 2 tahun 2012 Tentang Pengadaan tanah bagi pembngunan uantuk kepentingan umum menentukan bahwa:

Penilaian ganti kerugian dilakuakan dengan berdasarkan perturan perundangundangan, nilai ganti rugi yang dinilai oleh penilai adalah nilai disaat pengumuman penetapan ganti rugi lembaga pertanahan mengumpulkan penilaian yang telah ditetapkan untuk dilakukannya penilaian atas objek pengadaantanah, penilaian yang dilakukan bidang perbidang tanah meliputi:

Tanah

Ruang atas tanah dan bawah tanah

Bangunan

Tanaman

Benda yang berkaitan dengan tanah

Kerugian lain yang dapat dinilai

Musyawarah Penetapan ganti rugi

Lembaga pertanahan mengadakan musyawarah dengan masyarakat yang tanahnya terkena pengadaan yang dimana musyawarah ini diselenggarakan paling lama 30 hari pada hari kerja hasil penilaian dari tim penilai disampaikan kepada lembaga pertanahan untuk menentukan bentuk dan besarnya ganti kerugian yang akan diberikan kepada masyarakat. Hasil musyawarah inilah yang menjadi dasar dalam pemberian ganti kerugian.

Apabila terjadi ketidaksepakatan atas bentuk dan besarnya ganti kerugian dalam musyawarah tersebut pihak yang mersa keberatan dapat mengajukan keberatan terhadap Pengadilan Negeri setempat dengan batas waktu paling lambat 14 hari dari musyawarah penetapan ganti rugi. Pengadilan Negeri memutuskan bentuk dan barasan ganti rugi selama 30 hari kerja sejak keberatan tersebut diajukan, jika pihak yang mengajukan keberatan tersebut masih merasa keberatan atas putusan Pengadilan Negeri maka pihak yang berkeberatan tersebut dapat mengajukan kasasi kepada Mahkamah Agung dengan waktu 14 hari kerja, Mahkamah Agung memutuskan dalam waktu 30 hari kerja.

\section{Pemberian ganti rugi}

Pemberian ganti rugi hak atas tanah diberikan kepada masyarakat secara langsung kepada pihak yang berhak. Pemberian ganti rugi diberikan berdasarkan penilaian dari Musyawarah/Putusan Pengadilan Negeri/ Putusan Mahkamah Agung. Setelah pemerian ganti kerugian penerima ganti kerugian wajib:

\section{Dilakukannya pelepasan hak dan}

Memberikan bukti kepemilikan hak yang berupa penyerahan sertifikat terhadap instansi yang memerlukan tanah pemberian sertifikt ini diberikan kepada badan pertanahan badan pertanahanlah yang akan meroya sertifikat tersebut.

Berdasarkan hal tersebut maka mekanisme pemberian ganti kerugian dilakukan dengan cara musyawarah yang dimana dalam musyawarah ini dihapkan mencapai kata sepakat diantara masyarakat yang terkena pengadaan atau masyarakat pemegang hak atas tanah dengan pemerintah dan instansi yang bersangkutan dengan demikian pemegang hak atas tanah harus menjadi pertimbanagan dalam pengadaan tanah.

Tanah dalam masyarakat di Indonesia tidak hanya memiliki nilai ekonomis serta kesehjatraan semata tetpi juga menyangkut tentang maslah sosial, politik,kultur pisikilogis bahkan aspek-aspek lain misalnya aspek hukum dan pertanahan. Pemecahan masalah dalam pengadaan tanah memerlukan upaya pendekatan yang terpaduyakni meliputu pendekatan ekonomi, kesejahtraan, pendekatan politik, hukum dan sebagainya

Maka sehubungan dengan hal tersebut pengadaan tanah terutama dalam hal penetapan ganti rugi harus berdasarkan aspek sosial, ekonomi politik, religius dengan disertakan pada kemampuan pemerintah setempat. Menurut Ibu Ni Ketut Porda 
Mandayani,SH.,MH. Selaku kepala seksi pengadaan tanah pada kantor pertanahan Kabupaten Badung menerangkan bahwa aspek yang perlu diperhatikan dalam pengadaan tanah tidak dapet ditentukan secara pasti aspek pengadaan tanah menurut beliau tergantung pada situasi dan kondisi dari tanah yang terkena pengadaan tersebut, sebagai contoh misalkan tanah yang terkena pengadaan tersebut merupakan tanah yang dimana diatasnya terdapat pura maka aspek religius dari prngadaan tersebut harus diperhatikan .

Menurut Bapak Made Sucipta Loka selaku sub Fasilitas Pengadaan Tanah mengenai ganti rugi terhadap banguan dapat dibedakan atas beberapa kriteria yaitu:

Banguan permanen;

Bangunan semi permanen;

Bangunan darurat;

Dalam pengadaan tanah masyarakat mengira bahwa dalam ganti rugi harus menggunakan harga ummum setempat pandangan masyarakat ini menimbulkan persepsi bahwa harga tanah yang terkena pengadaan disamaratakn dengan harga tanah yang berada di kota maupun di wilayah kabupaten yang dimana harga di wilayah kota dan di wilayah kabupaten memiiki harga yang berbeda karena nilai tanah dilihat dari segi-segi seperti sosial, budaya dan religius.

Menurut Ibu Ni Ketut Phorda Mandayani, SH.,MH selaku kepala seksi Pengadaan Tanah Kantor Pertanahan Kabupaten Badung bahwa untuk kepentingan umum, pemerintah yang dimana hal ini pemerintah diwakilkan oleh panitia pengadaan tanah.

\section{Simpulan}

Berdasarkan uraian tersebut diatas dapat disimpulkan bahwa: Pengadaan tanah untuk kepentingan umum pada pelaksanaannya melakukan kegiatan pelepasan hak yang dimiliki oleh masyarakat hak tersebut merupakan hak kepemilikan tanah dimana tanah tersebut digunakan untuk kepentingan umum. Sebelumnya pengadaan tanah diatur dalam Permendagri Nomor 15 Tahun 1975 yang dimana pengadaan tanah disebut pembebasan tanah kemudian diganti dengan peraturan baru yaitu Perpres Nomor 71 Tahun 2012 Tentang Penyelenggaraan Pengadaan Tanah Bagi Pembangunan Untuk Kepentingan Umum dan dibentuknya Undang-Undang Nomor 2 Tahun 2012 Tentang Pengadaan Tanah Bagi Pembangunan Untuk Kepentingan
Umum. Sehingga kedua peraturan tersebut menjadi ladasan yuridis dalam pengadaan tanah berserta Undang-Undang Nomor 5 Tahun 1960 tentang Daspersiapan Pokok-Pokok Agraria, yang dimana prosedur pengadaan tanah bagi pembangunan untuk kepentingan umum dilakukan dengan 4 tahapan dimana tahapan tersebut tahap perencanaan pengadaan tanah, persiapan pengadaan tanah, pelaksanaan pengadaan tanah, dan menyerahkan hasil pengadaan tanah.

Mekanisme pemberian ganti rugi dalam pengadaan tanah yaitu terlebih dahulu dilakukannya penilaian ganti kerugian melalui musyawarah. Jadi dapat disimpulkan bahwa mekanisme pemberian ganti kerugian adalah harus melalui musyawarah. Dalam pemberian ganti kerugian aspek-aspek yang perlu diperhatikan yaitu aspek sosial, budaya, hukum, kemanusiaan, ekonomi, dan politik.

\section{DAFTAR PUSTAKA}

Mudakir Iskandar Syah, 2010, Pembebasan Tanah Untuk Pembangunan Kepentingan Umum, Jala Permata Aksara.

Novita, C. F. (2014). Tinjauan Hukum Terhadap Jual Beli Tanah Tanpa Akta PPAT (Wilayah Kecamatan Tinombo). Jurnal Ilmu Hukum Legal Opinion, 3 (2). Retrieved from https:// media.neliti.com/media/ publications/152126-ID-none.pdf

Parangi, E. (2008). Hukum Agraria Indonesia. Jakarta: Rajawali Pers.

Salindeho, J. (2008). Masalah Tanah Dalam Pembangunan. Jakarta: Sinar Grafika.

Syah, M. (2010). Psikologi Pendidikan dengan pendekatan baru. Bandung: PT Remaja Rosdakarya.

Syahri, R. A. (2014). Perlindungan Hukum Kepemilikan Hak Atas Tanah. Jurnal Ilmu Hukum Legal Opinion, 5(2). Retrieved from https://media.neliti.com/ media/publications/146453-IDperlindungan-hukum-kepemilikan-hakatas.pdf 